\title{
Contributors
}

\section{Karl Kalseth}

Karl Kalseth is department manager, Norsk Hydro Information Management Services, Oslo. He has been working with strategic planning and implementation of IRM within Norsk Hydro Corporate Staff.

\section{Patricia Hämäläinen}

Patricia Hämäläinen is senior information officer in the Information Services Department at Alko Ltd., Finland.

\section{Irene Wormell}

Dr. Irene Wormell is programme director and lecturer at the Royal School of Librarianship in Denmark. She has initiated the most important IRM (Information Resources Management) project in Denmark. Dr. Wormell runs her own consulting company, and has been actively promoting IRM-activities in several countries.

\section{Irene S. Farkas-Conn}

Dr. Irene S. Farkas-Conn is vice president of Arthur L. Conn \& Associates, an international consulting firm specializing in, among others, information resource management, based in Chicago, IL. She is former director of the Management-division of ASIS (American Society of Information Science). Dr. Farkas-Conn has been heavily engaged in numerous international conferences and expert seminars.

\section{Sven Hamrefors}

Sven Hamrefors has 15 years of experience in marketing and market research. $\mathrm{He}$ is project manager of UC Research, a department of Business Intelligence at Upplysnings Centralen AB, Sweden.

\section{Egon T.D. Bjerregaard}

Egon Bjerregaard is head of the Information Services Dept. of DTO (Danish Technical Information Service). He also acts as a consultant to private and public enterprises on technology and market opportunities. 


\section{Rudolf Krebs}

Rudolf Krebs is head of the Daimler-Benz Information and Documentation Centre in Stuttgart, Germany.

\section{Bertil Cederberg}

Bertil Cederberg is project manager, Information Provision at Asea Brown Boveri $A B$ Sweden. He has several years experience from managerial positions in library and information services.

\section{Sissel Sunde Thompson}

Sissel Sunde Thompson is manager, Norsk Hydro Information Management Services, Oslo, responsible for document handling activities. She has several years of experience as a librarian and staff member responsible for new information and documentation developments. 